\title{
Child labour is a matter of national concern: What is the curriculum doing about it?
}

\section{Anja Visser}

Education and Human Rights in Diversity Research, Faculty of Education, North-West University, Potchefstroom, South Africa

anja.visser@nwu.ac.za

https://orcid.org/0000-0002-9636-2326

(Received: 25 September 2020; accepted: 25 October 2021)

\section{Abstract}

Child labour has been of national and international concern since as early as the 1860s. In 2019 the United Nations General Assembly (UNGA) adopted the resolution that 2021 would be the year by which child labour would be eliminated. However, much must still be done to effect this. By studying legislation and literature, I identified different forms of child labour that I go on to discuss in this article. When I explored the notion of child labour from three perspectives on childhood, namely the romanticised view of childhood, the view that children must participate in child labour, and the belief that children need to be protected from the abuse and exploitation seen to be inherent in their working, I came to understand the tensions in conceptualising this concept. I further problematise child labour as an educational issue. One of the purposes of the South African compulsory school curriculum as articulated in the Curriculum and Assessment Policy Statement (CAPS) is to facilitate the transition of learners from education institutions to their future workplaces. I argue that CAPS should provide in-depth knowledge on the meaning of child labour in its different forms. For the purposes of this research, I analysed all the compulsory school curricula documents for Grades 1 to 9 by means of document analysis. My main finding is that CAPS does address some forms of child labour, but it does not address those forms (child work and illegal labour) with which most children would likely be confronted. Also, it does not address hazardous forms of child labour nor trafficking in child labour. More research is needed to determine if there are correlations between the results of this explorative document analysis and the received curriculum so that a curriculum response to address child labour can be articulated.

Keywords: child, curriculum, child labour, child work, trafficking

\section{Introduction}

Child ${ }^{1}$ labour is a multilayered complex concept and takes on different forms in legislation and literature. The term ranges from work that is beneficial to children (Bourdillon et al., 2009; Fyfe, 1988; Nsamenang, 2008) to what is defined as child labour (Gallinetti, 2008;

1 A child is defined as any person younger than 18 years of age in South Africa. 
South African Human Rights Commission, 2017). It includes legal and illegal labour (South African Government, 1997), along with hazardous forms of child labour (International Labour Organization, 1999), and trafficking for child labour (South African Government, 2013). Child labour is a matter of national concern and has been an international issue from as early as the 1860s (Fyfe, 2007).

Since 1919, the International Labour Organization (ILO) has tried to abolish child labour (International Labour Organization, 1919). However, Fyfe (2007) argued that it was only in the 1980s that the global movement against child labour began. Between 2000 and 2016, there was a global decrease of $38 \%$ in child labour cases. In 2016, it is estimated that 152 million children between the ages of 5 and 17 years were involved in child labour, with half of them (73 million) involved in hazardous practices and that these were more common in the 15 to 17 age group, but that still left 19 million children under the age of 12 involved in them (International Labour Organization, 2019a).

In 2019 the United Nations General Assembly (UNGA) adopted a resolution and declared that 2021 would be the international year for the elimination of child labour. UNGA adopted Transforming our World: The 2030 Agenda for Sustainable Development (United Nations, 2015). In this agenda, the Sustainable Development Goal 8.7 specifically and explicitly focusses on child labour (United Nations, 2015, p. 24)

Take immediate and effective measures to eradicate forced labour, end modern slavery and human trafficking and secure the prohibition and elimination of the worst forms of child labour, including recruitment and use of child soldiers, and by 2025 end child labour in all its forms.

According to the United States of America Department of Labor (2020, para. 1), South Africa has made "minimal advancement in efforts to eliminate worst forms of child labor." In this country, children are involved in the worst forms of child labour. The South African government did not include its elimination nor any prevention strategies in either the South African Education Plan or in the National Development Plan after this recommendation was made by the United States of America Department of Labor in 2019.

Apart from South Africa having to deal with illegal child labour, there is a need for "innovation in education to make youths better prepared for a society and labour market which has in many respects changed" (Department of Basic Education, 2019, p. 16). Other than learners being prepared to effectively transition from schools to other educational institutions, there should "also be clear linkages between education and training and the world of work" (National Planning Commission, 2011, p. 296).

One way in which education plays a role in addressing child labour is through the delivery of Curriculum and Assessment Policy Statement (hereafter CAPS). CAPS has several purposes. One of them that is directly related to the concerns of this article is that, overall, CAPS should be "facilitating the transition of learners from education institutions to the workplace" (Department of Basic Education, 2021). This transitioning could assume many forms such as, 
for example, a learner having the knowledge, skills, and attitudes to adjust to a workplace after having gained at school in-depth knowledge of the meaning of child labour in its different forms.

My aim in this article is to explore the extent to which the explicit South African Grade 1 to 9 school curriculum helps learners to transition from school to the workplace through addressing child labour. My assumption (and more empirical research is needed to test this) is that if learners were made aware of the different forms of child labour, it would help them in the process of transitioning from school (as an educational institution) to different workplaces. Child labour cannot be made to disappear just by addressing it in passing in the school curriculum; learners need to be made aware of the complexity of this issue if they are to be adequately protected against exploitation.

This was an exploratory study that aimed to provide some groundwork for further research. I employed document analysis as the research methodology, and this is the first time, to my knowledge, that the CAPS documents have been analysed in this way.

In the following sections, I trouble the conceptualisation of child labour by looking more closely at its different forms. Thereafter, I discuss this concept from different perspectives on childhood. I then look at education in relation to curriculum as a response to child labour. This is followed by a consideration of the research design. Finally, I discuss the findings and draw conclusions.

\section{Troubling the conceptualisation of child labour}

The conceptualisation of child labour is troubling given that this phenomenon has many different forms. As pointed out earlier, child labour refers to child work, child labour, legal and illegal child labour, hazardous forms of child labour, and trafficking for child labour.

Child work involves "virtually all economic activities, paid or unpaid, in or outside the home, including many chores traditional for children and generally considered part of acceptable child-rearing practice" (Bourdillon et al., 2009, p. 107). Child work is regarded as positive as long as it does not affect children's health, personal development, or school attendance (International Labour Organization, 2019b). Types of work can include helping with tasks at home, assisting in a family business, or earning pocket money after school and during school holidays. These types of work are beneficial to children's development, provide them with skills and experience, and prepare them for adult life (International Labour Organization, 2019b). Not every type of work done by children should be eliminated (Gallinetti, 2008) because children need to mature during childhood and should acquire all the skills and the capacity needed to be adults by the age of 18 (Sloth-Nielsen \& Mezmur, 2008).

Child labour is seen to be any work that "affects the child's enjoyment of his or her fundamental rights: civil, political or economic, social and cultural—particularly the broad right to survival and development of the child" (Gallinetti, 2008, p. 323), but child work can 
become child labour. The South African Human Rights Commission (2017, para. 4) defines child labour as

... work that is inappropriate with respect to the number of hours, and the conditions under which it is performed; work which deprives children of their livelihood, potential and dignity; and which interferes with or deprives children of education.

Referring specifically to the increasing suicide rate among Japanese children, Bourdillon (2000) questioned whether too much schoolwork is also exploitative and could be considered as harmful to children. Similarly, some household chores and other non-economic activities might be harmful to children and may violate their rights (Bourdillon, 2014) like, for example, when a child must do so much work at home that their schoolwork suffers, and they eventually have to drop out of school (Gallinetti, 2008).

Legal child labour has to do with the age group and the conditions under which children of this age work. Internationally and nationally, there is consensus that children aged 15 to 17 may be employed to do age-appropriate work that does not put them at risk (International Labour Organization, 1973; South African Government 1997). However, employers are legally prohibited from employing children under the age of 15 (this counts as illegal child labour), except for those involved in the performance of advertising, sports, artistic, or cultural activities (South African Government, 1997).

There are also hazardous forms of child labour. Article 3 of the Worst forms of child labour convention no 182 lists the following worst forms (International Labour Organization, 1999, para. 3):

a) all forms of slavery or practices similar to slavery, such as the sale and trafficking of children, debt bondage and serfdom and forced or compulsory labour, including forced or compulsory recruitment of children for use in armed conflict;

b) the use, procuring or offering of a child for prostitution, for the production of pornography or for pornographic performances;

c) the use, procuring or offering of a child for illicit activities, in particular for the production and trafficking of drugs as defined in the relevant international treaties;

d) work which, by its nature or the circumstances in which it is carried out, is likely to harm the health, safety or morals of children.

In legislation and literature, trafficking for child labour is defined as " $[\mathrm{t}]$ he recruitment, transportation, transfer, harbouring or receipt of a child for the purpose of exploitation" (United Nations, 2000, p. 2). In this case, exploitation involves forced labour or child labour, and sexual exploitation. This definition differs from others possibly because, in 2000, the Protocol to Prevent, Suppress and Punish Trafficking in Persons, Especially Women and Children (the Palermo Protocol) was the first international instrument to define trafficking in persons (United States Department of State, 2019). When children are involved, this act is considered to be exploitative and is classified as child trafficking (Conteh, 2009; United 
Nations Educational Scientific and Cultural Organization, 2007). This means that if a child is exploited for child labour, the said child is a victim of child trafficking for labour purposes.

Both the Palermo Protocol (United Nations, 2000) and South African legislation (South African Government, 2013) make a distinction between sexual exploitation on the one hand and child labour or forced labour for the purposes of exploitation for which children might be trafficked, on the other. However, as I highlighted earlier, the worst forms of child labour include trafficking and sexual exploitation.

As can be seen above, there are different interpretations that can be used when child labour is mentioned. The concept of child labour could be understood from different childhood perspectives, too.

\section{Conceptualising child labour from different perspectives on childhood}

The concept of childhood is constructed in different ways, depending on the nation, context, cultural group, and historical background (Louw \& Louw, 2014; Nsamenang, 2008). It was believed for many years that child development "follow[s] the same pattern of development in all countries and cultures" (Louw \& Louw, 2014, p. 13). Western researchers focussed almost exclusively on their own cultures and made conclusions about their research having implications for all children around the globe. However, recently researchers started to realise that the cultural context is important to the study of childhood. According to Louw and Louw (2014, p. 14), "[h]uman development is . . a cultural process. In every society, children are exposed to mostly cultural, not universal, influences." In this article, I focus on three views that cause tension in the interpretation of what child labour means.

\section{The romanticised view of childhood}

Romanticised ideas about childhood exist among societies with high-average incomes, developed infrastructure, and advanced technology. Work for children in this context is regarded as "strenuous learning" (Bourdillon, 2017, p. 93). Children spend much of their time in school, and they cannot participate in adult workplace activities. Since the late 18th century, romanticised childhood ideals have fostered an image of carefree, happy children playing, fantasising, being innocent, learning, being free from responsibility, properly protected, and dependent on their caregivers (Bourdillon, 2017; Cunningham \& Viazzo, 1985; Stephens, 1995). From this perspective, children need to be protected and segregated from the harsh realities of adulthood (Stephens, 1995), and they are economic dependents rather than productive participants in the economy (Nsamenang, 2008).

Bourdillon (2017) argued that the wealthy can afford to provide this childhood for their children, but this has come to be seen as ideal for all. In addition, according to Nsamenang (2011, p. 235), not only the ideal of a romanticised childhood but also developmental indicators developed in the Global North have been "forced" on the rest of the world. The 
romanticised view of childhood has inspired campaigners and advocates against child labour (Bourdillon, 2014; Cunningham \& Viazzo, 1985). From this viewpoint, "productive work by children is perceived as inhibiting schooling and hindering development and therefore should be abolished" (Bourdillon, 2017, p. 93). According to Nsamenang (2008, p. 211), the active productive participation of African children in the economic activities of their families and communities "has been stigmatized as child labour by international advocacy and children's rights interveners." However, Louw and Louw (2014) argued that, since children were being exploited, sold into slavery, and subjected to abuse, the Convention on the Rights of the Child and many other movements were born. Clearly, there is a tension in the literature, and in reality, regarding what kind of child labour is positive for children's development and should not be abolished and what kind should indeed be eliminated.

\section{Children participating in child labour}

As underscored earlier, child labour can be beneficial to children; this form of child labour is known as child work. Bourdillon (2014, p. 3) disparages child labour discourse since it "focuses only on harmful aspects of work and ignores the benefits that children may derive from it." In other words, when the benefits of child work are appreciated, one would not assume that all work is exploitative. When children are viewed with romanticised ideals in mind, they are protected from adulthood, and this creates an artificial dichotomy between adults and children as Bourdillon (2017) pointed out.

In South Africa, as has already been noted, the minimum age of employment is 15 years (South African Government 1997). Bourdillon et al. (2009, p. 107) urged "re-thinking the 'minimum-age' approach" to child work and labour. They make this argument because there is no scientific research to determine the real impact of age-restriction policies on children. In their view, the minimum-age approach is based on romanticised views of childhood and does not take due account of realities: child work that does not restrain children from going to school could help them to finance the cost of their and their siblings' school attendance.

Anthropological and child development studies demonstrate that children thrive in a great diversity of childhoods, including many that carry important work responsibilities. The unsupported idea that work itself distorts and corrupts children's development nonetheless remains popular among both the public and policymakers. In most of the world, children's participation in work is a common way of learning essential life skills, such as parenting, and major occupational skills such as farming. (Bourdillon et al., 2009, p. 110)

In Africa, the division between adults and children is not that straightforward. Children participate in family enterprises, and it is a natural part of their growing up and learning how to live in their social context. According to Bourdillon (2017, p. 92), an essential feature of "good-quality child rearing" is to require children to work to contribute to the household and community. Not only African children work; many children in high-income countries obtain part-time work like, for example, delivering newspapers or goods or working at food outlets. This broadens children's experience; they gain an income, they have more social contacts, 
and they learn to deal with the world in which they are growing up. These children value the life skills they acquire through working, and they claim that work teaches them skills and knowledge they cannot learn in a classroom (Bourdillon, 2014).

Some societies consider work to be integral to bringing up a child and even complementary to their schooling (Bourdillon et al., 2009). In the African context, children are given the opportunity to engage in tasks, chores, and traditions of adulthood before the age of 18 . Engaging in these practices is viewed as part of growing up to learn how to assume responsibility and acquire skills to prepare them for life (Sloth-Nielsen \& Mezmur, 2008). Child work is seen as essential to preparing the next generation, and it is seen to be necessary for their developmental learning (Nsamenang, 2011). Bourdillon $(2014$, p. 1) further pointed out that "[m]any African societies run their affairs on the ingrained notion that children must work as part of their process of growing up."

\section{Children need to be protected from abuse and exploitation}

In Africa, children have been sold into slavery during inter-tribal raids since the earliest times (Louw \& Louw, 2014). From the 15th to the 17th century, slavery was a lucrative business, and children, men, and women were shipped to various countries. Although slavery or human trafficking is illegal today, it is still practised in many countries (Louw \& Louw, 2014).

The African continent has the highest proportion of children involved in child labour. Approximately 72.1 million children in Africa are involved in child labour, and 31.5 million African children are involved in hazardous work (Alliance 8.7, 2017). Nsamenang (2008, p. 217) stated that "various forms of child labor, child abuse and child enslavement are also increasingly present in the African context." Since children cannot willingly participate in exploitation and are often coerced or manipulated into situations from which they are trafficked and the economic conditions in which they find themselves often lead them to make an unfree choice to participate in trafficked child labour (Visser, 2018). It is not only criminals who target children; disease, poverty, civil strife, the complexities of globalisation, and the world trading system all make children susceptible to exploitation (Gallinetti, 2008).

Some child labours are hazardous and hinder children's development (Bourdillon, 2014). In some cases, children are abused in their workplaces, but it is not always clear when child labour can be regarded as hazardous (Bourdillon, 2014). Some lists identifying hazardous child labour have been compiled and Bourdillon (2014) argued that these lists focus on some particularly hazardous work, ignoring situations in which children are abused and do not focus as much on the kind of work they do. Furthermore, exploitation is not defined in the context of child labour although, for adult labour, this refers to a wide variety of factors, such as unfair remuneration, harmful working conditions, and so on. When children are employed, the employment itself is defined as exploitation, so, "instead of attending to conditions of work, authorities stop children from working" (Bourdillon, 2014, p. 10).

The first view I discussed above emphasises an ideal childhood in which children are protected from the harsh realities of adulthood, are not exposed to work and live happy lives, 
whereas the second view focusses on the realities some children face. By participating in child work, they create better futures for themselves and their communities. The third view shows us that children need protection from child labour when such labour is exploitative and abusive. The reality of many South African children is that they will most likely work from a young age, and they might not have the knowledge to identify exploitative and abusive labouring conditions. Some children can work and be in school without this being harmful to their development. In fact, this could be good for them and for their future employability but they need to know what counts as being exploitative. In this regard, CAPS has a responsibility to address the necessity for knowledge about child labour. The following questions can be raised: How does the curriculum prepare children to identify normal versus exploitative and abusive labouring conditions? And how does CAPS prepare children to know when child work is not abusive and a good opportunity in which to participate?

\section{Education and curriculum as a response to child labour}

In South Africa, school attendance is compulsory and a human right for all children between the ages of 7 and 15 (South African Government 1996a, 1996b). Despite it being mandatory for children aged 7 to 15 to attend school, South African schools have a drop-out crisis. Nearly half of the learners enrolled in Grade 1 drop out of the schooling system before they reach Grade 12 (Smillie \& Mobotja, 2019; South African Government, 2011). South Africa should ensure that all children of compulsory school-going age attend school, drop-outs should be monitored more closely, and individual cases must be followed up (Department of Basic Education 2019).

When children leave school, it is often to find a job to support their families (Gallinetti, 2008). In 2015, almost 600,000 South African children were engaged in child labour. Children in the age group of 16 to 17 are more likely than others to be involved in child labour (South African Human Rights Commission, 2017).

Although legislation such as the African Charter on the Rights and Welfare of the Child (Organization of African Unity, 1990), the South African Constitution (South African Government 1996a), the Prevention and Combating of Trafficking in Persons Act (South African Government, 2013), among others is in place to protect children against child labour, children are still exploited in a number of working environments. Root causes of child labour are poverty, a poor education system, and cultural influences. To combat child labour, direct interventions such as raising awareness and sound education are needed (International Labour Organization, 2017). Since child labour and education are "inextricably" (International Labour Organization, 2017, p. 9) linked, support from the education sector is imperative. This is reflected in Article 7.2 of Worst forms of child labour convention no 182 that clearly stipulates that each member state should take "into account the importance of education in eliminating child labour" (International Labour Organization, 1999, para. 12). In addition, these member states should ensure access to free basic education (International Labour Organization, 1999). What is more, one of the four pillars of anti-trafficking interventions is prevention since this is a key component in the reduction of factors that allow trafficking to 
happen. One of the ways of preventing trafficking is to raise awareness through education (Department of Basic Education 2019).

Given the educational focus on the analysis of CAPS, more clarity on what is meant by curriculum is needed. Curriculum Studies can be viewed from a narrow or a broad perspective according to Graham-Jolly (2003). A narrow view of curriculum defines it only as a syllabus concerned with the selection and revision of content and does not consider other aspects that contribute to learning, whereas a broad perspective takes into consideration a comprehensive understanding of what curriculum is including what happens in the classroom as well as the actual experiences of learners. Curriculum, in its broadest sense, should help prepare children to confront many challenges in adulthood (Soudien \& Chisholm, 2021).

In Curriculum Studies, there are two major schools of thought about how to interpret curriculum (Du Preez, 2017), namely curriculum as knowledge, and curriculum as policy (Chisholm, 2005). These schools of thought have different origins and stress different features of a curriculum.

The first school of thought, curriculum as knowledge, according to Chisholm (2005) stresses knowledge construction and the role of the school in teaching and learning. At its heart is constructivism and outcomes-based education with its learner-centred focus. This approach brings to the surface the "local, hidden, silenced knowledge, and everyday realities of learners" (p. 194). Learner-centred education enables the validation of hidden knowledge and everyday realities so that real learning can take place (Chisholm, 2005). Du Preez (2017) argued that curriculum as knowledge can be associated with the conceptual-empiricist paradigm as discussed by Pinar (2009). Critics of this school of thought indicate that it focusses on the "local, known, and everyday" that is not seen as education, because at the heart of an educational endeavour is "a leading away from the known, familiar, and everyday into universal processes" (Chisholm, 2005, p. 194). Conceptual empiricism is inclined to make curriculum too context-specific, just as the social construction of knowledge is the focus in the view of curriculum as knowledge (Du Preez, 2017).

The second school of thought, curriculum as policy, places emphasis on the symbolic aspect of policy and on curriculum's political character, on the history of policy, on the conflicts between curriculum in theory and practice, and on the relationship between curriculum and identity (Chisholm, 2005). Du Preez (2017, p. 107) describes curriculum as policy since the "politicisation of curriculum matters, and the unfolding of symbolic notions embedded in a curriculum." For curriculum-as-policy scholars, "curriculum is a fundamentally political statement that reflects the struggles of opposing groups to have their interests, values, histories, and politics dominate the school curriculum" (Chisholm, 2005, p. 194). According to Du Preez (2017), curriculum as policy can be associated with the reconceptualist paradigm, as discussed by Pinar (2009). Reconceptualist scholars are concerned with the political character of education and its historical legacy (Du Preez, 2017). According to Du Preez (2017, p. 107), "This movement is less concerned with empirical means to justify curriculum development and quality and more orientated towards metatheory and philosophy of curriculum-related knowledge in larger growth of social science episteme." 
CAPS can be interpreted from both schools of thought. South Africa is faced with economic inequalities, and therefore schools and the schooling system must continually "make a conscious effort to heal the divisions of the past, foster a sense of South African nationhood and, above all, provide education opportunities that will break down the deep inequalities that still pervade South African society" (Department of Basic Education 2019, p. 4). According to the World Bank (cited in Department of Basic Education, 2019, p. 10), "[e]conomic development is recognised as critical for fighting poverty, and in this fight education plays a central role."

CAPS can also be positioned in a bigger discourse. Colonisers developed school systems in Africa to model education on the countries of their origin. In doing so, they ignored the needs of the social development of the colonised societies (Bourdillon, 2017). Throughout the 20th century, schools were viewed as representative of the most, and often the only, legitimate site of learning (Bessel, 2017). Furthermore, Bourdillon (2017, p. 92) argued that "[g]lobal policy on children's work and education is dominated by two assumptions." The first of these is that schooling is the best way to secure a future for all children, and the second is that work in general hinders schooling and should therefore be avoided during childhood. Local communities are not taken into consideration in these global assumptions that might be true for high-income societies where caregivers take economic responsibility. However, in the African context, these assumptions are not always valid, since African children actively participate in economic activities (Bourdillon, 2017). Nsamenang (2011, p. 243) stated that, in African cultures, "responsibility is more valued than cognition, per se, in that a child or adolescent cannot be responsible without being cognitive." According to Bourdillon (2014, p. 16), policies have been dominated by "the norms that have been established in the West and are assumed to be ideal for all children everywhere, with little attention to the precise contexts and needs of children in other situations, nor to outcomes in children's lives."

\section{Research design, methodology, and main findings}

This study involved me in document analysis situated within an interpretivist paradigm. I downloaded all CAPS for Grades 1 to 9 compulsory subjects from the Department of Basic Education's website. Table 1 presents a list of the CAPS documents that I analysed. The data was generated by a limited set of information; only the explicit curriculum was analysed and neither teachers' lesson plans nor prescribed textbooks were included. The purpose of the study was to describe how the Grade 1 to 9 school curriculum helps learners transition from school to the workplace through addressing child labour. 


\section{Table 1}

South Africa's compulsory Grade 1 to 9 explicit curriculum

\begin{tabular}{|c|c|c|c|}
\hline Phase & Grades & Subject & $\begin{array}{l}\text { Department of } \\
\text { Basic Education }\end{array}$ \\
\hline \multirow{4}{*}{ Foundation phase } & Grades 1-3 & English First Additional Language & $(2011 a)$ \\
\hline & Grades 1-3 & English Home Language & $(2011 b)$ \\
\hline & Grades R-3 & Life Skills & $(2011 c)$ \\
\hline & Grades 1-3 & Mathematics & $(2011 d)$ \\
\hline \multirow{6}{*}{ Intermediate phase } & Grades 4-6 & English First Additional Language & $(2011 \mathrm{e})$ \\
\hline & Grades 4-6 & English Home Language & $(2011 f)$ \\
\hline & Grades 4-6 & Life Skills & $(2011 \mathrm{~g})$ \\
\hline & Grades 4-6 & Mathematics & (2011h) \\
\hline & Grades 4-6 & Natural Sciences and Technology & (2011i) \\
\hline & Grades 4-6 & Social Sciences & $(2011 \mathrm{j})$ \\
\hline \multirow{9}{*}{ Senior phase } & Grades 7-9 & Creative Arts & $(2011 k)$ \\
\hline & Grades 7-9 & Economic and Management Sciences & $(20111)$ \\
\hline & Grades 7-9 & English First Additional Language & $(2011 \mathrm{~m})$ \\
\hline & Grades 7-9 & English Home Language & $(2011 n)$ \\
\hline & Grades 7-9 & Life Orientation & (2011o) \\
\hline & Grades 7-9 & Mathematics & (2011p) \\
\hline & Grades 7-9 & Natural Sciences & $(2011 q)$ \\
\hline & Grades 7-9 & Social Sciences & $(2011 r)$ \\
\hline & Grades 7-9 & Technology & (2011s) \\
\hline
\end{tabular}

I carefully analysed all the curriculum documents presented in Table 1 and present the findings below.

\section{Main Findings}

A search for the key term child labour in all the CAPS documents produced a poor result. Inductive identification of concepts discussed in CAPS that can be related to labour and/or child labour resulted in "career", "employment", "job", "labour", “occupation", "slavery", "slave(s)", and "work." I decided to search deductively for these specific concepts by making use of content analysis. Table 2 below displays the frequency of concepts related to child labour in the Grade 1 to 9 explicit curriculum. 


\section{Table 2}

Frequency of explicit mentions of concepts related to child labour in the compulsory Grade 1 to 9 explicit curriculum

\begin{tabular}{|c|c|c|c|c|c|c|c|c|}
\hline Subject & 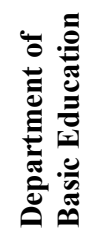 & U் & 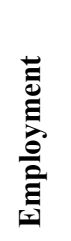 & $\stackrel{\circ}{\circ}$ & 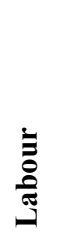 & 节 & 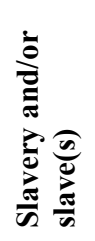 & $\frac{4}{\vdots}$ \\
\hline \multicolumn{9}{|l|}{ Foundation phase } \\
\hline Grades 1-3 English First Additional Language & 2011a & 0 & 0 & 0 & 0 & 0 & 0 & 0 \\
\hline Grades 1-3 English Home Language & $2011 b$ & 0 & 0 & 0 & 0 & 0 & 0 & 0 \\
\hline Grades R-3 Life Skills & $2011 \mathrm{c}$ & 0 & 0 & 0 & 0 & 0 & 0 & 0 \\
\hline Grades 1-3 Mathematics & $2011 d$ & 0 & 0 & 0 & 0 & 0 & 0 & 0 \\
\hline \multicolumn{9}{|l|}{ Intermediate phase } \\
\hline Grades 4-6 English First Additional Language & $2011 \mathrm{e}$ & 0 & 0 & 1 & 0 & 0 & 0 & 0 \\
\hline Grades 4-6 English Home Language & $2011 f$ & 0 & 0 & 1 & 0 & 0 & 0 & 0 \\
\hline Grades 4-6 Life Skills & $2011 \mathrm{~g}$ & 0 & 0 & 0 & 0 & 0 & 0 & 0 \\
\hline Grades 4-6 Mathematics SA & $2011 \mathrm{~h}$ & 0 & 0 & 0 & 0 & 0 & 0 & 0 \\
\hline Grades 4-6 Natural Sciences and Technology & $2011 \mathrm{i}$ & 1 & 0 & 1 & 0 & 0 & 0 & 0 \\
\hline Grades 4-6 Social Sciences & $2011 \mathrm{j}$ & 0 & 0 & 1 & 2 & 1 & 0 & 4 \\
\hline \multicolumn{9}{|l|}{ Senior phase } \\
\hline Grades 7-9 English First Additional Language & $2011 \mathrm{~m}$ & 1 & 1 & 3 & 0 & 0 & 0 & 0 \\
\hline Grades 7-9 English Home Language & $2011 n$ & 1 & 1 & 3 & 0 & 0 & 0 & 0 \\
\hline Grades 7-9 Life Orientation & 20110 & 46 & 1 & 0 & 0 & 0 & 0 & 27 \\
\hline Grades 7-9 Mathematics & $2011 p$ & 0 & 0 & 0 & 0 & 0 & 0 & 0 \\
\hline Grades 7-9 Natural Sciences & $2011 \mathrm{q}$ & 10 & 0 & 0 & 0 & 0 & 0 & 0 \\
\hline Grades 7-9 Technology & $2011 \mathrm{~s}$ & 7 & 0 & 9 & 0 & 0 & 0 & 0 \\
\hline Grades 7-9 Social Sciences & $2011 \mathrm{r}$ & 0 & 0 & 0 & 8 & 0 & 35 & 6 \\
\hline Grades 7-9 Creative Arts & $2011 \mathrm{k}$ & 22 & 0 & 0 & 0 & 0 & 0 & 0 \\
\hline Grades 7-9 Economic and Management Sciences & 20111 & 0 & 1 & 2 & 3 & 0 & 0 & 0 \\
\hline
\end{tabular}

Below, I discuss the subjects that address the concept of child labour.

\section{Creative Arts}

Creative Arts (CA) explicitly mentions the concept of career (Department of Basic Education, 2011k) with regard to different career paths that learners can take. One of the specific aims of CA "is to expose learners to the range of careers in the arts" (p. 8). Table 3 gives the overview of media and careers, one of the topics covered in CA during the senior phase (Grade 7 to 9), as it is set out in the CAPS document for CA. 
Table 3

Topic 5 - Media and careers in CA (Department of Basic Education, 2011k, p. 16)

\begin{tabular}{|l|l|l|l|}
\hline Topic & Grade 7 Drama & Grade 8 Drama & Grade 9 Drama \\
\hline $\begin{array}{l}\text { Topic 5 } \\
\text { Media and } \\
\text { careers }\end{array}$ & $\begin{array}{l}\text { Exploration: } \\
\text { Performers } \\
\text { The creative team } \\
\text { The support team } \\
\text { Related fields of study }\end{array}$ & $\begin{array}{l}\text { Accessible and relevant } \\
\text { media } \\
\text { Media forms such as film, } \\
\text { television, radio, } \\
\text { documentaries and the } \\
\text { internet } \\
\text { Drama elements in the } \\
\text { selected media form }\end{array}$ & $\begin{array}{l}\text { Positive and negative effects } \\
\text { of media } \\
\text { Stereotyping (including } \\
\text { typecasting, labelling, stock } \\
\text { characters) in stories, theatre, } \\
\text { film, television and radio } \\
\text { Stereotyping according to } \\
\text { age, gender, class/status and } \\
\text { culture, etc. }\end{array}$ \\
\hline
\end{tabular}

During the second term, Grade 7 learners are expected to write a test on careers and basic drama elements and, in the fourth term, to write an examination on careers and elements of drama. In Grade 7, learners are expected to explore:

- performing careers, including actors (theatre, film), dancers, singers, clowns, stand-up comedians, etc. (the support team, including the stage manager, stage hands, make-up artists, costume mistress, props mistress, lighting and sound technicians and front of house staff (p. 37).

- the related fields of study, including the drama teacher, drama therapist, drama life coach, voice and speech therapist, movement therapist, radio and television presenters, master-of-ceremonies and agents (p. 38).

Grade 8 learners are expected to learn about dance and related careers, fashion design careers in the arts, and careers in the arts and design fields. In Grade 8, learners are expected to "[e]xpress, identify/name, question and reflect through researching careers in visual arts and design using various sources, e.g. books, libraries, internet; formal written response or class presentation (could be group work)" (p. 72). In the third term, they are expected to write an essay or do a presentation on "Visual Literacy: Careers in the arts" (p. 86). In the fourth term, learners are expected to write an examination that includes the topic of careers.

In Grade 9, the teacher is expected to make use of books on careers.

\section{Economic and Management Sciences}

Economic and Management Sciences (EMS) explicitly refers to the concepts of employment, job, and labour (Department of Basic Education 20111). In this subject, learners study labour, financial markets, and the creation of sustainable job opportunities (p. 14). When learners study the factors of production, they learn about unskilled, semi-skilled and skilled labour, as well as fair employment practices. For one hour a week, during weeks 4 to 6 in term 2 of Grade 8, learners are expected to learn about "Capital - borrowed and own capital; labour skilled, semi-skilled and skilled labour; role of workers in the business; fair employment practices; natural resources, entrepreneurship, remuneration of the factors of production" ( $p$. 17). 


\section{Languages}

In Intermediate Phase English First Additional Language and English Home Language, the term "job" is used as part of a list of the text types that should be used to enable all learners to learn how to write an official letter for various purposes, such as "to apply for a job or bursary; to complain, request, etc." (Department of Basic Education, 2011e, p. 25; Department of Basic Education, 2011f, p. 27).

In Senior Phase First Additional Language and Home Language, the words "career", "employment" and "job" are explicitly mentioned. The first sentence of section 3 that specifically deals with teaching plans states, "The Senior Phase is, to most unfortunate learners, the end of compulsory education. After Grade 9, most learners either go looking for a job or follow vocational careers" (Department of Basic Education, 2011m, p. 55; 2011n, p. 55). Employment is used in the context of setting up a curriculum vitae (CV), and one of the elements of a CV is to "address the post for which the candidate seeks employment" $(2011 \mathrm{~m}$, p. 44; 2011n, p. 44). "Job" is also mentioned in the context of setting up a CV: "It is useful to note that every $\mathrm{CV}$ must address a situation, e.g., a CV for a particular job should speak mainly of the writer's involvement in that particular area" (2011m, p. 44; 2011n, p. 44). In addition, "job" is used in the context of filling in a form for various reasons, such as applying for a job, among others (2011m; 2011n).

\section{Life Orientation}

Life Orientation (LO) explicitly mentions "career", "employment”, and "work." In LO, learners are "guided to develop their full potential and are provided with opportunities to make informed choices regarding personal and environmental health, study opportunities and future careers" (Department of Basic Education, 2011o, p. 8). Specific aim 4 of LO is to "guide learners to make informed and responsible decisions about their health, environment, subject choices, further studies and careers" (p. 9). In Grade 7, learners are expected to learn about "place or institution of employment" (p. 14). Topic 5 in LO is dedicated to the "world of work" (SA, p. 8). In Table 2, an overview of the content addressed in Topic 5, "world of work", is provided. 


\section{Table 4}

Topic 5 ("world of work") in LO (SA, 2011o, pp. 10, 12-14, 16-18, 2023)

\begin{tabular}{|c|c|c|}
\hline Grade 7 (8 Hours) & Grade 8 (9 Hours) & Grade 9 (11 Hours) \\
\hline Term 1: Weeks 9-10 (2 hours) & Term 1: Week 10 (1 hour) & Term 1: Week 8-10 (3 hours) \\
\hline $\begin{array}{l}\text { - Importance of reading and studying } \\
\circ \text { Reading for enjoyment and reading with } \\
\text { understanding } \\
\circ \quad \text { Skills to develop memory: ability to recall }\end{array}$ & $\begin{array}{l}\text { Different learning styles: visual aural, kinaesthetic, } \\
\text { reading and writing } \\
\circ \quad \text { Identify own learning style }\end{array}$ & $\begin{array}{l}\text { - Time-management skills } \\
\circ \text { How to organise one's work } \\
\circ \text { How to use time effectively and efficiently } \\
\text { - Reading and writing for different purposes } \\
\circ \quad \text { Keeping a journal; summarising and improving } \\
\text { reading and writing skills }\end{array}$ \\
\hline Term 2: Weeks 6-8 (3 hours) & Term 2: Week 1 (1 hour) & Term 2: Weeks 6-8 (3 hours) \\
\hline \multirow{3}{*}{$\begin{array}{l}\text { Career fields: } \\
\text { ○ Qualities relating to each field: interests and } \\
\text { abilities } \\
\circ \text { School subjects related to each career field } \\
\circ \text { Work environment and activities in each career } \\
\text { field } \\
\circ \text { Opportunities within each career field } \\
\circ \text { Challenges within each career field } \\
\circ \quad \text { Level of schooling - requirements for each } \\
\text { career field } \\
\circ \quad \text { Duration of study for each career field } \\
\circ \quad \text { Services and sources for career fields and study } \\
\text { information }\end{array}$} & - Identify and apply own learning style & \multirow{3}{*}{$\begin{array}{l}\text { - Options available after completing Grade 9: National } \\
\text { Senior Certificate (NSC - Grades } 10-12) \text { and } \\
\text { National Certificate Vocational (NCV }- \text { FET } \\
\text { Colleges) qualifications } \\
\text { Implications of choices: choices between NSC } \\
\text { and NCV } \\
\text { Knowledge of the world of work: rights } \\
\text { responsibilities and opportunities in the workplace }\end{array}$} \\
\hline & Term 2: Weeks 2-5 (4 hours) & \\
\hline & $\begin{array}{l}\text { - Six career categories: investigative, enterprising, } \\
\text { realistic, artistic, conventional and social } \\
\circ \text { Interests and abilities related to each career } \\
\text { category } \\
\text { Thinking and learning skills required by each } \\
\text { career category } \\
\circ \text { School subjects related to each career category } \\
\text { The role of work in relation to South Africa's social } \\
\text { and economic needs } \\
\circ \text { Identify needs in the community and country } \\
\circ \text { How work can meet social and economic needs } \\
\text { in South Africa }\end{array}$ & \\
\hline
\end{tabular}




\begin{tabular}{|c|c|c|}
\hline Grade 7 (8 Hours) & Grade 8 (9 Hours) & Grade 9 (11 Hours) \\
\hline Term 3: Weeks 8-10 (3 hours) & Term 3: Weeks 1-3 (3 hours) & Term 3: Weeks 1-3 (3 hours) \\
\hline \multirow{3}{*}{$\begin{array}{l}\text { - Simulation of career related activities } \\
\circ \text { Dress code for the career } \\
\circ \text { Tools or working equipment for the career } \\
\circ \text { Activities related to work environment } \\
\circ \text { Place or institution of employment } \\
\circ \text { Personality characteristics } \\
\circ \text { School subjects and level of schooling: } \\
\text { requirements for this career } \\
\circ \text { Where to study and duration of study } \\
\circ \text { Related careers } \\
\text { Value and importance of work in fulfilling personal } \\
\text { needs and potential }\end{array}$} & \multirow[t]{3}{*}{$\begin{array}{l}\text { - Relationship between performance in school subjects } \\
\text { and interests and abilities } \\
\circ \quad \text { Types of learning activities related to different } \\
\text { subjects: practical, theoretical, individual or } \\
\text { group activities } \\
\text { Demands of each subject: thinking and learning } \\
\text { skills required } \\
\text { - Decision-making process } \\
\text { Steps in choosing career category relating to } \\
\text { individual strength, ability, interest and passion }\end{array}$} & $\begin{array}{l}\text { - Career and subject choices } \\
\circ \text { Subjects in Grades } 10,11 \text { and } 12 \\
\circ \quad \text { Careers related to different subjects } \\
\circ \quad \text { Qualities relating to different careers and } \\
\text { subjects: strengths and weaknesses; interests and } \\
\text { abilities } \\
\circ \quad \begin{array}{l}\text { Decision-making skills: steps in choosing } \\
\text { subjects relating to interests and abilities and } \\
\text { career of interest }\end{array}\end{array}$ \\
\hline & & Term 4: Weeks 1-2 (2 hours) \\
\hline & & $\begin{array}{l}\text { - Study and career funding providers } \\
\text { - Plan for own lifelong learning: goal-setting for } \\
\text { lifelong learning }\end{array}$ \\
\hline
\end{tabular}




\section{Natural Sciences and Technology}

In Intermediate Phase Natural Sciences and Technology (NST), the terms "career" and "job" are found in Specific Aim 3: "Similarly, Science and Technology can lead learners to a range of career and job possibilities" (Department of Basic Education, 2011i, p. 11).

In Senior Phase Technology, the terms "career" and "job" are explicitly mentioned. In Technology, the concept of career is explicitly mentioned in the introductory section of the document that states, "It is expected that Technology education will provide learners with some experience to help them to make career-oriented subject choices at the end of Grade 9" (Department of Basic Education, 2011s, p. 9). Career is also used in the section on the unique features and scope of Technology. In the latter section, it is stated that learners will have the opportunity to learn "while creating positive attitudes, perceptions and aspirations towards technology-based careers" (p. 9) and also that "[t]echnology education is an introduction to a range of careers that work in similar ways" (p. 11). Examples are provided of careers that use design, for example, "[c]ivil engineering - designing a bridge, architecture - designing a house, textile design - developing a textile for a specific purpose" (p. 11). In Technology, Grade 8 learners are expected to participate in a class discussion on "equitable sharing of resources - industry needs reliable power for job creation; schools need power for lightning and computing" (p. 28).

In the Senior Phase, Natural Sciences (NS) specifically refers to "career" (Department of Basic Education, 2011q). NS pays attention to different career paths, even though learners are not assessed on different careers in this subject (SA, 2011q). In Grade 7, learners are expected to discuss careers in:

- the chemical industry, including agriculture, pharmacy or the food industry, chemical engineering, mining [not for assessment purposes] (p. 21);

- chemistry, mining, waste management [not for assessment purposes] p. 21);

- the field of electricity power generation (coal, nuclear, wind, water) including engineers, scientists (research), artisans, technicians [not for assessment purposes]. (p. 30)

Grade 8 learners should be:

- discussing about [sic] the many careers that require knowledge of environmental studies, nature conservation, zoology, botany, entomology, the study of microorganisms, including agriculture, food industry, medicine [not for assessment purposes] (p. 39);

- discussing / reading about careers in inorganic and organic chemistry, mining, engineering, materials development and in the bio-fuels industry [not for assessment purposes] (p. 45);

- finding out about careers in electrical engineering, (such as electricians) electronics, electricity supply maintenance [not for examination purposes] (p. 49); 
- discussing about [sic] careers in optics, physics, optical transmission of information (fibre optics) [not for assessment purposes] (p. 51);

- discussing the many opportunities in SA for careers in astronomy [not for assessment purposes]. (p. 55)

Grade 9 learners should be:

- reading about careers in the chemical industry, including agriculture, pharmacy, chemical engineering, mining [not for assessment purposes] (p. 69);

- discussing the many careers in the energy sector, including electricians, electrical engineers, artisans, IT specialists for maintaining and improving the power grid. (p. 76)

\section{Social Sciences}

In the Intermediate Phase, the Social Sciences (SS) curriculum explicitly mentions "job", "labour", "occupation", and "work" (Department of Basic Education, 2011j).

In Grade 4, learners are expected to learn about "people and places", including "work: jobs people do in different places" (p. 21).

In Grade 5, learners are expected to learn about "[ $t$ ]he first farmers in southern Africa". This topic includes "[t]ools and weapons from iron and copper: division of labour: gender-based activity: men" and "[d]ivision of labour: gendered activity: women" (p. 39). They are also expected to learn that " $\mathrm{t}] \mathrm{h}$ he entry of farmers did not end the occupation of hunter-gatherers" (p. 39).

In Grade 4, one of the recommended resources is "[p]hotographs of people working on farms" (p. 23). In Grade 5, learners learn about mining and the people who work in mines, more specifically about " [c]hallenges of working in a deep gold mine - such as ventilation, heat, rock falls, dust" (p. 28). Learners learn about the first farmers in Southern Africa and more specifically about "[a] culture of co-operation, e.g., communal work parties during the ploughing season, helping a newcomer by lending calves for a year or two" (p. 39). They also learn about "[t]ools and weapons from iron and copper" with the focus on "[m]etal working (iron, smelting and fire technology, smithery) (p. 39). In Grade 6, learners learn about fairtrading, more specifically "[t]he human cost of unfair trade - work and exploitation" (p. 30).

In the Senior Phase, the SS curriculum explicitly mentions the terms "labour", "slavery", "slaves", and "work" (Department of Basic Education, 2011r).

Grade 7 learners learn about "[t]he kingdom of Mali and the city of Timbuktu 14th century" and that slaves were traded across the Sahara Desert (p. 33). The transatlantic slave trade is one of the overview topics in Grade 7. When Grade 7 learners learn about the transatlantic slave trade, the following content and concepts are covered (p. 34):

- West Africa before the European slave trade; 
- The nature of slavery in West Africa before Europeans;

- Slavery in the American South;

- The impact of the transatlantic slave trade on slaves;

- The impact of the transatlantic slave trade on the economies of West Africa, America, and Britain - gains for America and Britain, and the negative impact on West Africa.

Moreover, Grade 7 learners learn about "[c]olonisation of the Cape 17th-18th centuries" (p. 35 ). In this topic, slaves at the Cape and the movement of trekboers with their slaves and servants are covered. Grade 7 learners also learn about the abolition of slavery in 1836 and about runaway slaves. Grade 8 learners learn about the wealth from slave trade during the Industrial Revolution in Britain.

Grade 8 learners learn about the Industrial Revolution in Britain and Southern Africa from 1860 and focus on:

- Changes during the Industrial Revolution in Britain, focusing on "[ $\mathrm{t}]$ he mines and factories - child labour in mills and mines" and "[1] abour, resistance, the trade union movement and working class organisations" (p. 37)

- Southern Africa by 1860: Indentured labour from India to work on sugar plantations in a British colony of Natal and they attend to "[r]easons why labour was imported: Zulu kingdom was still independent" and "[c]onditions under which indentured labourers lived and worked" (p. 37)

Grade 8 learners learn about the mineral revolution in South Africa (Department of Basic Education, 2011r). Here, they learn about how "labour [was] established and continued into the 20th century" (p. 37). One of the themes they learn about is "Britain, diamond mining and increasing labour control and land expansionism" with more attention on "[i] Increasing control over black workers: closed compounds and migrant labour" (p. 38). Another theme Grade 8 learners cover is "[d]eep-level gold mining on the Witwatersrand 1886 onwards", with special attention on "[m] igrant workers" and "[f]orms of labour resistance" (p. 38).

\section{Mathematics, Life Skills, and Foundation Phase subjects}

Languages in the Foundation Phase do not address any concepts related to child labour. This is also true of Life Skills for the Foundation and Intermediate Phases as well as of Mathematics in all the phases.

\section{Discussion}

To explore how and to what extent the Grade 1 to 9 curriculum addresses different forms of child labour, I examined all the compulsory CAPS documents. In this section, I reflect on the main findings from a curriculum-as-policy perspective. CAPS documents are political, and so is the concept of child labour. The different views on how to interpret the concept of child labour are all supported by a different political agenda. The focus of this article is the expectation that CAPS should prepare children for the workplace and labour market 
(Department of Basic Education, 2011, 2019). Since child labour is a multilayered complex concept, explaining how it is addressed in CAPS is not an easy task. CAPS addresses the following aspects:

Work that is beneficial: There are no direct references to child work that is beneficial for children.

Child labour: Child labour is mentioned once in SS for Grade 8 learners (Department of Basic Education (2011r, p. 37). Content is provided on child labour in mills and mines during the Industrial Revolution in Britain.

Legal labour: It seems that CAPS focusses mostly on legal labour for persons older than 18 years of age. In Languages, learners learn how to write a letter to apply for a job and how to create a CV. Careers are addressed in Creative Arts, Technology, and Natural Sciences. EMS and NST address job creation. EMS focusses some attention on technical aspects regarding labour, financial markets, factors of production, including unskilled, semi-skilled and skilled labour, fair employment practices, and the role of workers in business. SS provides a historical overview of different working environments, such as farming in South Africa, mining (gold and diamonds), and metalworking. SS addresses the division of labour as a gendered activity. LO is the subject that devotes the most time to the world of work (Department of Basic Education, 2011o, pp. 10, 12-14, 16-18, 20-23). The main points addressed by LO are: the importance of reading and studying; career fields; simulation of career-related activities; different learning styles; six career categories; the role of work in relation to South Africa's social and economic needs; the relationship between performance in school subjects and interests and abilities; decision-making processes; time-management skills; reading and writing for different purposes; options after completing Grade 9; knowledge of the world of work; career and subject choices; study and career funding providers; and plan for own lifelong learning.

Illegal child labour: CAPS is silent on the issue of children working before they are 15 years of age.

Hazardous forms of child labour: SS also addresses slavery, child labour, fair and unfair trading, work and exploitation, labour resistance, imported labourers, indentured labourers, the abolition of slavery, and runaway slaves.

Trafficking for child labour: CAPS is silent on the issue of trafficking for child labour.

It seems that CAPS, to some extent, is preparing learners for the workplace, but for what type of workplace? Is it an idealised one underpinned by a romanticised view of childhood? Is it assumed that children will start school in an early childhood development centre, then progress to Grade 12, apply for a diploma or university degree, apply for a job in their career of choice, and be appointed to their dream job? What about the children who do not live the reality of such a romanticised childhood and who must work from an early age to help support other family members? 
In this article, I have mentioned that child work can be beneficial (Bourdillon, 2014; Nsamenang, 2008; Sloth-Nielsen \& Mezmur, 2008) and will most likely be the reality for many children in Africa, including South Africa. What makes this particularly challenging is that South African children have the option of leaving school at the age of 15 or at the end of Grade 9 to start working, and even more problematic is South Africa's school drop-out crisis (Smillie \& Mobotja, 2019). Like many other children of 15 years of age and older, they go to work so that they can help support their families (Gallinetti, 2008). It seems that CAPS does not consider workplaces for children and how to prepare Grade 1 to 9 learners to enter the workplace at the end of Grade 9. This means that learners are not equipped to face the realities they might encounter when they drop out of school to start working. Those who are fortunate enough to find legal work opportunities should be able to learn how to make themselves more employable by, for example, knowing how to find advertisements for legal work opportunities, how to read a work contract, what the minimum remuneration for employment is, and how to obtain information on legal labour practices for children. Apart from not being well-prepared for the world of work, school-leavers at the age of 15 might not know what their rights are in a working environment. This could mean that they become victims of illegal labour, or worse, victims of hazardous forms of child labour or trafficking for child labour. This is a matter of real concern in Africa, a country that has the highest proportion of children involved in child labour (Alliance 8.7, 2017).

Education is an important means of fighting the exploitation of child labour (International Labour Organization, 2017), including hazardous forms of child labour and trafficking for child labour. Yet South Africa's explicit school curriculum does not teach learners about the dangers of these forms of child labour. CAPS addresses some concepts of hazardous forms of child labour but much of the focus on slavery is on adults and not on child slaves. The stark fact is that South African children who do not grow up in a romanticised childhood do not have access to knowledge about child labour. They need this knowledge to help them understand the different forms of child labour and to become aware of hazardous forms of child labour and trafficking for child labour that they might be exposed to when they leave school.

\section{Conclusion}

In this article, I provide a broad understanding of child labour from a perspective that focusses on curriculum as policy. CAPS does address child labour, but the assumptions that appear to have been made about childhood that underpin the curriculum content are questionable and should be interrogated. These assumptions might lead to an understanding of why CAPS is silent about some forms of child labour. South African children do not have equal opportunities in terms of their employability and future workplaces yet CAPS does not help these learners transition from school to workplace. Empirically based research on teachers to discover more about how the planned curriculum addresses child labour and research involving learners to learn more about the received curriculum on child labour might shed more light on this. More insight is needed from people who have been exploited by involvement in hazardous forms of child labour or child trafficking for labour if we are to 
explore the impact of having knowledge (or not) about these forms of labour. Moreover, empirical research is needed to explore how CAPS helps learners in the age group of 16 to 17 to transition from school to the workplace. Finally, more research is needed to determine if there are correlations between this explorative document analysis and the received curriculum so that a curriculum response to address child labour can be formulated.

\section{References}

Alliance 8.7. (2017). Regional brief for Africa: 2017 global estimates of modern slavery and child labour.

https://www.ilo.org/wcmsp5/groups/public/@ed_norm/@ipec/documents/publication/ wcms_597869.pdf

Bessel, S. (2017). Education, school, and learning: Dominant perspectives. In T. Abebe \& J. Waters (Eds.), Laboring and learning (pp. 91-110). Springer.

Bourdillon, M. F. C. (2000). Child labour and education: A case study from south-eastern Zimbabwe. Journal of Social Development in Africa, 15, 5-32.

Bourdillon, M. F. C. (2014). Introduction: Children's work in Africa. In M. Bourdillon \& G. M. Mutambwa (Eds.), The place of work in African childhoods (pp. 1-20). Council for the Development of Social Science Research in Africa.

Bourdillon, M. F. C. (2017). Labor as education. In T. Abebe \& J. Waters (Eds.), Laboring and learning (pp. 91-110). Springer.

Bourdillon, M. F. C., White, B., \& Myers, W. E. (2009). Re-assessing minimum-age standards for children's work. International Journal of Sociology and Social Policy, 29, 106-117.

Chisholm, L. (2005). The making of South Africa's National Curriculum Statement. Journal of Curriculum Studies, 37(2), 193-208.

Conteh, M. (2009). Child trafficking, child prostitution and the potential dangers of the 2010 FIFA World Cup in South Africa. In O. C. Ruppel (Ed.), Children's rights in Namibia (pp. 375-390). Macmillan Education Namibia.

Cunninghum, H., \& Viazzo, P. P. (1985). Some issues in the historical study of child labour. In H. Cunningham \& P. P. Viazzo (Eds.), Child labour in historical perspective 1800-1985 - case studies from Europe, Japan and Colombia (pp. 7-10). United Nations Children's Fund.

Department of Basic Education. (2011a). National Curriculum Statement. Foundation Phase. Grades 1-3. English First Additional Language. Government Printers. 
Department of Basic Education. (2011b). National Curriculum Statement. Foundation Phase. Grades R-3. English Home Language. Government Printers.

Department of Basic Education. (2011c). National Curriculum Statement. Foundation Phase. Grades R-3. Life Skills. Government Printers.

Department of Basic Education. (2011d). National Curriculum Statement. Foundation Phase. Grades 1-3. Mathematics. Government Printers.

Department of Basic Education. (2011e). National Curriculum Statement. Intermediate Phase. Grades 4-6. English First Additional Language. Government Printers.

Department of Basic Education. (2011f.) National Curriculum Statement. Intermediate Phase. Grades 4-6. English Home Language. Government Printers.

Department of Basic Education. (2011g). National Curriculum Statement. Intermediate Phase. Grades 4-6. Life Skills. Government Printers.

Department of Basic Education. (2011h). National Curriculum Statement. Intermediate Phase. Grades 4-6. Mathematics. Government Printers.

Department of Basic Education. (2011i). National Curriculum Statement. Intermediate Phase. Grades 4-6. Natural Sciences and Technology. Government Printers.

Department of Basic Education. (2011j). National Curriculum Statement. Intermediate Phase. Grades 4-6. Social Sciences. Government Printers.

Department of Basic Education. (2011k). National Curriculum Statement. Senior Phase. Grades 7-9. Creative Arts. Government Printers.

Department of Basic Education. (20111). National Curriculum Statement. Senior Phase. Grades 7-9. Economic and Management Sciences. Government Printers.

Department of Basic Education. (2011m). National Curriculum Statement. Senior Phase. Grades 7-9. English First Additional Language. Government Printers.

Department of Basic Education. (2011n). National Curriculum Statement. Senior Phase. Grades 7-9. English Home Language. Government Printers.

Department of Basic Education. (20110). National Curriculum Statement. Senior Phase. Grades 7-9. Life Orientation. Government Printers.

Department of Basic Education. (2011p). National Curriculum Statement. Senior Phase. Grades 7-9. Mathematics. Government Printers.

Department of Basic Education. (2011q). National Curriculum Statement. Senior Phase. Grades 7-9. Natural Sciences. Government Printers. 
Department of Basic Education. (2011r). National Curriculum Statement. Senior Phase. Grades 7-9. Social Sciences. Government Printers.

Department of Basic Education. (2011s). National Curriculum Statement. Senior Phase. Grades 7-9. Technology. Government Printers.

Department of Basic Education. (2019). Action plan to 2024: Towards the realisation of schooling 2030.

https://www.education.gov.za/Portals/0/Documents/Publications/Sector\%20plan\%202 019\%2015\%20Sep\%202020.pdf?ver=2020-09-16-130709-860

Department of Basic Education. (2021). National Curriculum Statements (NCS) Grades R 12.

https://www.education.gov.za/Curriculum/NationalCurriculumStatementsGradesR12.aspx

Du Preez, P. (2017). Classical theories and theorists of curriculum studies. In L. Ramrathan, L. Le Grange \& P. Higgs (Eds.), Education studies for initial teacher development (pp. 95-111). Juta.

Fyfe, A. (1988). Child labour. Polity Press.

Fyfe, A. (2007). The worldwide movement against child labour: Progress and future directions. International Labour Office.

Gallinetti, J. (2008). Worst forms of child labour: A view from out of Africa. In J. SlothNielsen (Ed.), Children's rights in Africa: A legal perspective (pp. 323-341) Ashgate.

Graham-Jolly, M. 2003. The nature of curriculum. In M. Coleman, M. Graham-Jolly \& D. Middlewood (Eds.), Managing schools in South Africa: Managing curriculum in South African Schools (pp. 3-63). Commonwealth Secretariat.

International Labour Organization. (1919). Minimum Age (Industry) convention no 5 of 1919.

International Labour Organization. (1973). Minimum Age convention no 138 of 1973.

International Labour Organization. (1999). Worst forms of child labour convention no 182 of 1999.

International Labour Organization. (2017). Meta-analysis of evaluations on ILO child labour programmes and projects in Africa 2009-2014. International Labour Organization.

International Labour Organization. (2019a). 2021 declared international year for the elimination of child labour. https://www.ilo.org/global/about-theilo/newsroom/news/WCMS_713925/lang--en/index.htm 
International Labour Organization. (2019b). What is child labour. https://www.ilo.org/ipec/facts/lang--en/index.htm

Louw, D., \& Louw, A. 2014. Child and adolescent development (2nd ed.). Psychology Publications.

National planning commission. (2011). National development plan 2030: Our future - make it work. https://www.gov.za/sites/default/files/gcis_document/201409/ndp-2030-ourfuture-make-it-workr.pdf

Nsamenang, A. B. (2008). Agency in early childhood learning and development in Cameroon. Contemporary issues in early childhood, 9(3), 211-223.

Nsamenang, A. B. (2011). The culturalization of developmental trajectories: a perspective on African childhoods and adolescences. In L. A. Jensen (Ed.), Bridging cultural and developmental approaches to Psychology: New syntheses in theory, research, and policy. (pp. 235-253). Oxford University Press.

Organization of African Unity. (1990). African Charter on the Rights and Welfare of the Child. https://www.refworld.org/docid/3ae6b38c18.html

Sloth-Nielsen, J., \& Mezmur, B. D. (2008). A dutiful child: The implications of article 31 of the African Children's Charter. Journal of African Law, 52, 159-189.

Smillie, S., \& Mabotja, K. (2019). Matric Results: Drop-out crisis in SA schools. https://www.iol.co.za/saturday-star/news/matricresults-drop-out-crisis-in-sa-schools18693946

Soudien, C., \& Chisholm, L. (2021). A re-examination of key curriculum debates and directions in South Africa.

http://repository.hsrc.ac.za/bitstream/handle/20.500.11910/15945/11923.pdf?sequence $=1 \&$ is Allowed $=\mathrm{y}$

South African Government. (1996a). Constitution of the Republic of South Africa 1996. Government Printer.

South African Government. (1996b). South African Schools Act no 84 of 1996. Government Printer.

South African Government. (1997). Basic Conditions of Employment Act no 75 of 1997. Government Printer.

South African Government. (2005). Children's Act no 38 of 2005. Government Printer.

South African Government. (2013). Prevention and combatting of trafficking in persons Act no 7 of 2013. Government Printer. 
South African Human Rights Commission. (2017). Child labour is exploitative and violates the rights of the child. https://www.sahrc.org.za/index.php/sahrc-media/news2/item/673-child-labour-is-exploitative-and-violates-the-rights-of-the-child

Stephens, S. (1995). Introduction. Children and politics of culture 'late capitalism'. In S. Stephens (Ed.), Children and the politics of culture (pp. 3-48). Princeton University Press.

United Nations. (2000). Protocol to prevent, suppress and punish trafficking in persons, especially women and children, supplementing the United Nations convention against transnational organized crime. United Nations.

United Nations. (2015). Transforming our world: the 2030 agenda for sustainable development. https://sustainabledevelopment.un.org/content/documents/21252030\%20Agenda\%20f or\%20Sustainable\%20Development $\% 20$ web.pdf

United Nations Educational Scientific and Cultural Organization. (2007). Human trafficking in South Africa: Root causes and recommendations. United Nations Educational Scientific and Cultural Organization.

United States of America Department of Labor. (2020). Child labor and forced labor reports: South Africa. https://www.dol.gov/agencies/ilab/resources/reports/child-labor/southafrica

Visser, A. (2018). Narratives of child trafficking survivors in rehabilitation: Conceptualisations of freedom for human rights education (Unpublished doctoral dissertation). North-West University, RSA. 